\title{
Transforaminal escape of a lumbar epidural catheter
}

\begin{abstract}
A patient is presented whose lumbar epidural catheter was found to lie in the paravertebral tissues during a right radical nephrectomy. The catheter had been placed with the patient awake and the procedure performed in a routine fashion without difficulty or indication of catheter malposition. Four $\mathrm{ml}$ of $2 \% \mathrm{CO}_{2}$ lidocaine were initially injected as a test dose without any demonstrable effect. After the induction of general anaesthesia. fentanyl $100 \mu$ and $0.25 \%$ bupivacaine $10 \mathrm{ml}$ were injected slowly into the catheter. Previous studies suggest that transforaminal escape of an epidural catheter occurs after $1-6 \%$ of insertions. It may occur without nerve root symptoms during catheter placement. The authors recommend that epidural catheters be introduced whilst the patients are awake and an effective block demonstrated before induction of general anaesthesia.
\end{abstract}

Ce rapport clinique décrit un patient chez qui un cathéter inséré dans l'espace péridural avant l'induction anesthésique a été retrouvé dans les tissus paravertébraux au cours d'une néphrectomie radicale droite. L'insertion du cathéter s'est faite sans difficulté et sans évidence de faux trajet. Une dose test de $4 \mathrm{ml}$ de lidocaïne $2 \%$ carbonatée fut d'abord injectée par le cathéter sans effet secondaire. Après l'induction d'une anesthésie générale, $100 \mu \mathrm{g}$ de fentanyl et $10 \mathrm{ml}$ de bupivacaine $0,25 \%$ ont été injectés lentement par le cathéter. Des études antérieures ont démontré que 1 à $6 \%$ des cathéters insérés dans l'espace péridural pouvaient migrer à travers les trous de conjugaison. Cecin'est pas toujours accompagné de symptômes indiquant une atteinte des racines nerveuses. Les auteurs recommandent que l'insertion des cathéters périduraux se fassent chez le patient

\section{Key words}

ANAESTHETIC TECHNIQUES: epidural; COMPLICATIONS: catheter migration.

From the Department of Anaesthesia, Foothills Hospital, Calgary, Alberta.

Address correspondence to: Dr. David Halpenny, Department of Anaesthesia, Vancouver General Hospital, Room 3200 - 910 West 10th Avenue, Vancouver, B.C., V5Z 1M9.

Accepted for publication 28th February, 1992.
David G. Halpenny MD, Rock G. Loken MD BSc FRCP, John A. Williams MD FRCS éveillé et qu'un bloc sensitif etou moteur soit mis en évidence avant l'induction d'une anesthésie générale.

\section{Case report}

A 79-yr-old woman presented for a right radical nephrectomy due to renal cell carcinoma. She had a history of coronary artery disease, hypertension, non insulin dependent diabetes mellitus and peripheral vascular disease. She had no previous history of back or spine pathology. After obtaining the patient's consent, it was decided to utilize a combined regional and general anaesthetic technique. The epidural catheter was also to be used for postoperative pain control.

Upon arrival in the operating room, an intravenous catheter was placed and blood pressure, ECG, and pulse oximetry monitors were connected. She was placed on her left side and her back was prepared and draped. Using a sterile technique, the $\mathrm{L}_{4-5}$ lumbar interspace was identified and a 17-gauge Tuohy needle was inserted in the midline. The epidural space was located with a loss of resistance technique using an air filled glass syringe. A 20-gauge epidural catheter (Preferred Medical Products - closed end, multi-port, nylon catheter without stylet) was threaded in a cephalad direction without resistance $4 \mathrm{~cm}$ beyond the needle tip. At no time did the patient complain of pain or paraesthesia. The Tuohy needle was removed and the catheter was secured to the patient's back.

The patient then resumed a supine position. After confirming a negative aspiration for blood and/or CSF, $2 \%$ $\mathrm{CO}_{2}$ lidocaine, $4 \mathrm{ml}$, was infused via the catheter. After four minutes there was no evidence of subarachnoid block and general anaesthesia was induced with fentanyl, 100 $\mu \mathrm{g}$, followed by thiopentone, $275 \mathrm{mg}$. Muscle relaxation was achieved with vecuronium, $6 \mathrm{mg}$, and the trachea was intubated. Anaesthesia was maintained with $50 \%$ nitrous oxide, and isoflurane, $0.5-1.5 \%$. Shortly after induction, fentanyl, $100 \mu \mathrm{g}$ in $8 \mathrm{ml}$ saline and bupivacaine $0.25 \%$ (without epinephrine), $10 \mathrm{ml}$, were slowly infused into the epidural catheter. This did not produce any change in blood pressure.

Surgery proceeded via a right subcostal incision with the patient in the supine position. The right kidney was removed and near the end of the operation, when the 


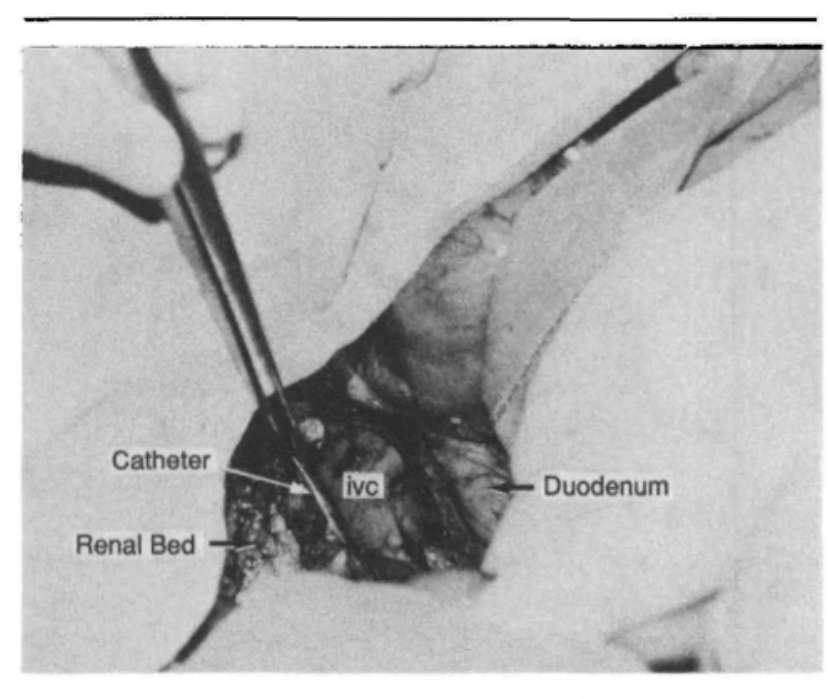

FIGURE Epidural catheter being lifted by surgeon's forceps. IVC inferior vena cava.

surgeon was examining the renal bed, the distal portion of the epidural catheter was seen. The tip of the catheter was lying parallel to the inferior vena cava at the $\mathrm{L}_{2}-\mathrm{L}_{3}$ level. Retrograde dissection revealed the catheter emerging from the anterior vertebral fascia at the $\mathrm{L}_{3}-\mathrm{L}_{4}$ level (Figure). Verification was achieved by injecting normal saline through the catheter. It was then easily removed by the anaesthetist under direct vision.

The patient was awakened and her postoperative course was uneventful.

\section{Discussion}

The lateral boundaries of the epidural space consist mainly of the periosteum of the vertebral pedicles and the intervertebral foramina. The nerve roots exit from each foramen covered with epineurium which is continuous with the dura. Surrounding the nerves at the foramen is the lobulated areolar tissue of the epidural fat. The density of this areolar tissue varies considerably but there is no tissue or ligament to prevent the escape of local anaesthetic (or a catheter) from the intervertebral foramen. With advancing age, this areolar fat becomes a recognizable "operculum" that effectively blocks off these spaces. ${ }^{1}$

In 1960 , Hehre et al. $^{2}$ reported a series of 1780 epidural catheters with a $2 \%$ failure rate. Fourteen of the 36 nonfunctioning epidurals were made functional by partially withdrawing the catheters. Twenty-two others were left untouched and their positions were confirmed radiologically. Sixteen of these were found to have emerged through the intervertebral foramina. Only half of these patients experienced paraesthesia during catheter insertion.

Sanchez et al. ${ }^{3}$ performed a similar radiological study in 1967 with 90 catheters inserted to distances ranging from
8 to $16 \mathrm{~cm}$. He had a $6 \%$ incidence of transforaminal catheter exit. Similarily, Bridenbaugh et al., ${ }^{4}$ in a series of 198 epidural catheters, described an incidence of transforaminal escape of $4.5 \%$. Moir and Willocks ${ }^{5}$ demonstrated an incidence of clinical catheter failure of only $1 \%$ in a series of 30 obstetrical patients.

This case illustrates what may be one of the more common causes of epidural catheter failure. Migration can occur without eliciting paraesthesia during insertion and in the absence of threading an excessive length of catheter into the epidural space. In an effort to avoid catheter complications or failure, we suggest that epidural catheters be placed in awake patients. Small doses of local anaesthetic should be injected to rule out subarachnoid or intravenous injection. Then, a slightly larger dose of local anaesthetic should be injected to demonstrate an appropriate blockade before anaesthesia is induced. This will insure that catheters utilized during general anaesthesia are in the epidural space.

\section{References}

1 Cousins MJ. Neural Blockade. 2nd ed. Philadelphia: J B Lippincott Company, 1988; 255-70.

2 Hehre FW, Sayig J, Lowman RM. Etiological aspects of failure of continuous lumbar peridural anesthesia. Anesth Analg 1960; 39: 511-7.

3 Sanchez A, Acuna L, Rocha F. An analysis of the radiological visualization of the catheters placed in the epidural space. Br J Anaesth 1967; 39: 485-9.

4 Bridenbaugh LD, Moore DC, Bagdi P, Bridenbaugh PO. The position of plastic tubing in continuous block-techniques: an $x$-ray study of 552 patients. Anesthesiology 1968; 29: 1047-9.

5 Moir DD, Willocks J. Epidural analgesia in British obstetrics. Br J Anaesth 1968; 40: 129-38. 